\title{
The derivation and interpretation of left peripheral discourse particles
}

\author{
Josef Bayer \& Andreas Trotzke \\ University of Konstanz
}

\section{Introduction}

In this chapter, we focus on an exceptional case of syntactic configurations involving discourse particles (DiPs) in German. It is generally claimed that German DiPs like denn (lit. 'then') or nur (lit. 'only') are, unlike adverbs, stuck in the middle field of the clause. To see this, consider a minimal pair involving the adverb/DiP vielleicht (lit. 'perhaps').

(1) a. Der ist vielleicht SÜSS.

this.MASC is perhaps sweet

'This one (e.g. coffee) is perhaps sweet.'

b. Vielleicht ist der SÜSS.

'Perhaps, this one is sweet.'

(2) a. DER ist vielleicht süß!

this.one (e.g. a cute little dog) is PART sweet

'My god, how sweet it is!'

b. *Vielleicht ist DER süß!

(intended: same as 2a)

In its function as an adverb, vielleicht may be fronted as in (1b); in its function as a DiP, howev$\mathrm{er}$, this is impossible as seen in (2b). Although positional rigidity is a highly reliable property of DiPs, wh-questions with DiPs seems to present an exception. Consider (3a, particle in bold) and the alternative in (3b).

(3) a. Wie habe ich nur den Schlüssel verlieren können? (Abraham 1991: 237) how have I PART the keys lose could

b. Wie nur habe ich den Schlüssel verlieren können?

'How on earth could I lose the key?' 
In (3b), wh+DiP must form a constituent because German is a V2 language which usually disallows more than a single constituent to the left of the finite verb (SpecCP) of the main clause. This phenomenon is well documented in the literature (Bayer \& Obenauer 2011; Meibauer 1991, 1994; Thurmair 1989). In this chapter, we deal with the following two issues: (i) How can we derive the exceptional word order we see in (3b)? (ii) Do the different word orders given in (3a) and $(3 \mathrm{~b})$ correspond to different semantic or pragmatic interpretations?

Working in a strictly derivational system as provided by the Minimalist Program, we will not consider the possibility of deriving (3b) from (3a). In such a case, the wh-phrase would have to undergo merger with the DiP at the stage of [nur den Schlüssel wie verlieren können], in violation of the 'Extension Condition' (see also below), and then move on with the DiP by depriving the structure of the scope position that the DiP appears to occupy. ${ }^{1}$ In order to address the questions in (i) and (ii) seriously, we will take a different route. The paper is structured as follows. In section 2, we turn to the derivation of left peripheral particles and provide a successive-cyclic movement account for the distribution of German discourse particles in the left periphery of the clause. Relying on the combination of key aspects of the Minimalist Program, we develop a derivational model that can also account for the seemingly problematic cases of stacked particles appearing in the left periphery. In section 3, we turn to the interpretation of configurations involving left peripheral particles. In comparison with the unmarked construction, we notice an interpretive distinctness which as we argue requires the notion of emphasis for intensity to account for the extra pragmatic effect these structures convey. Section 4 summarizes and concludes the paper.

\section{The derivation of left peripheral particles}

As we said above, it is generally observed that, unlike adverbs, discourse particles like German denn (lit. 'then') or nur (lit. 'only') are immobile. This follows if the particles are heads that are rooted in the functional structure of the clause as suggested in (4); cf. Cardinaletti (this volume) and Hinterhölzl \& Munaro (this volume) for alternative approaches. Notice that the DiP, abbreviated here as 'Prt', is in the scope of Force/Fin because the choice of Prt depends on major categories of Force.

(4) $\left[\right.$ ForceP/FinP Force $\left.^{0} / \operatorname{Fin}^{0}\left[(\operatorname{TopP}) \ldots\left[\operatorname{Prt}^{0}\left[\left(\operatorname{AdvP}^{*}\right)[\mathrm{vP} / \mathrm{vP} \ldots]\right]\right]\right]\right]$

As already mentioned in the introduction, an important qualification must be added to the claim that DiPs are syntactically immobile: various such particles can appear as a co-constituent of a

1 Cf. Bayer \& Obenauer (2011: §4) who argue that the DiP heads a particle phrase which would be 'decapitated' in the course of this derivation. 
wh-element, and in this case they move along with the wh-element to the left periphery of the clause (cf. $3 b$ above). According to the literature, the [wh+Prt]-construction is compatible with the DiPs schon, denn, auch, überhaupt, eigentlich, nur, wohl, blo.$^{2}$

In what follows, we first demonstrate that the $w h$-element and the particle in these constructions should be analyzed as one constituent (section 2.1). We then turn to the issue of how this constituent is merged into the derivation and to the question of how [wh+Prt] reaches the left periphery of the clause (section 2.2). Based on this analysis, we will show that our approach can also account for cases of stacked particles in the left periphery (section 2.3).

\subsection{Left peripheral particles and syntactic constituency}

In German minimal clauses containing a fronted finite verb, there is maximally one XP constituent in front of the finite verb, as exemplified by (5). This is known as the V2 constraint.

(5) a. [Nach der Aufführung am Abend] hat Hans eine Jacke an. after the performance in.the evening has Hans a jacket on

'After the performance in the evening, Hans is wearing a jacket.'

b. * [Nach der Aufführung] [Hans] hat eine Jacke an.

Turning to cases of left peripheral particles, Bayer (1996) has argued for focus particles that they are functional heads that project a 'particle phrase'. This claim is challenged by approaches that refer to particles as maximal projections that adjoin to already existing phrases, cf. Jacobs (1983) for an early account, and various researchers that accepted it, cf. Büring \& Hartmann (2001); Sternefeld (2006); Kleemann-Krämer (2010) and others. This results in a V3 analysis of constructions involving left peripheral particles (cf. Müller 2003, 2013 for data on V3 in general).

(6) Nur Peter kooperierte heute.

(Büring \& Hartmann 2001)

a. V3 analysis

[CP nur $[\mathrm{CP}$ Peter $[C$, kooperierte $[\ldots[$ heute...] $]] \ldots]]$

b. V2 analysis

[cP [nur Peter] [C, kooperierte [... [heute...]]]...]

[PrtP [Prt' nur Peter]

There are several arguments against a V3 analysis of left peripheral focus particles (e.g. Meyer \& Sauerland 2009; Reis 2005). Bayer $(1996,1999)$ discusses examples such as (7b), which can only

2 The particle doch is an exception. It can only occur (non-adjacently) with gleich, as in Wer doch war das gleich? ('Who was it again?'), cf. Meibauer (1991: 228). 
be explained by postulating a particle phrase where the XP (here: einer) moves to the specifier of the particle phrase.

(7) a. [Nur einer] hat gelacht.

only one has laughed

'Only one person laughed.'

b. [Einer nur] hat gelacht.

Notice that in (6a) nur cannot c-command the (obligatory) focus on Peter unless it precedes it. The linear order seen in (7b) cannot be explained because nur would not c-command the focus. Concerning these cases, Büring \& Hartmann (2001: 240) claim that "[m]ost speakers, including both authors of this article, indeed find sentences like [(7b)] unacceptable. Standard grammars of German likewise do not mention this placement of F[ocus]P[article]s as a possibility." However, this construction is a regular option in German syntax and authentic examples abound (cf. Reis 2005 and references cited there).

In the context of DiPs, examples such as (3), repeated here for convenience as (8), provide important evidence for head status of particles and against a characterization as regular adverbs with a 'special' semantic interpretation (Manzini this volume) or as 'deficient' adverbs in the sense of Cardinaletti (2011, this volume). Note that [wh+Adv]-constructions such as (9) violate the V2 constraint.

(8) Wie nur habe ich den Schlüssel verlieren können?

(9) a. *[Wenoft $]$ hat er getroffen? who often has he met
b. * [Wen vielleicht] hat er verpasst? ${ }^{3}$ who perhaps has he missed

Several constituency tests suggest that the wh-element and the particle form one constituent; cf. (10) for evidence from sluicing and (11) for corpus examples involving coordination (obtained from the DWDS corpus, cf. Klein \& Geyken 2010).

(10) A: Irgendeinerhat das Geld gestohlen.

Someone has the money stolen

3 Evaluative adverbs like leider are ruled out for other reasons because they are always marked or even ungrammatical in questions, cf. Bellert (1977) and Ernst (2007) for discussion of speaker-oriented adverbs in questions. 
B: Aber [wer nur]?

But who PART

* B': Aber [wer] vielleicht?

But who perhaps

(11) a. Nie hätte ich mich damals mit ihm unterhalten - wie auch und worüber? neverhad I myself back.then with him talked how PART and what.about 'Never had I talked to him back then - and anyway, how and what about?

(Die Zeit, 04.10.1991, Nr. 41)

b. Zwei Alpenländler, die auszogen, im hohen Norden das two people.from.the.Alpine.countries which set.out in.the Far North the Telemarken zu lernen. Aber wo nur und worauf? telemarking to learn but where PART and whereon 'Two people from the Alpine countries that set out to learn telemarking in the Far North. But where at all and whereon?'

(Die Zeit, 06.12.1991, Nr. 50)

If we consider only the DiPs, we observe that particles, even if compatible with assertive speech acts (cf. 13b), can never appear in the prefield alone (cf. 13 and 2b above), while adverbs can (cf. 12 and $1 b$ above).

(12) a. Oft hat er ihn getroffen. often has he him met 'He has often met him.'

b. Vielleicht hat er ihn getroffen. perhaps has he him met 'He has perhaps met him.'

(13) a. * Denn hat er ihn getroffen. b. * Ja hat er ihn getroffen. ${ }^{4}$

4 This concurs with the finding that quantifying elements such as genau can also appear in the left periphery together with wh-elements, but never alone.

(i) Wann genau hat er ihn getroffen?

when exactly has he him met

'When exactly has he met him?'

(ii) * Genau hat er ihn getroffen.

In section 3, however, we will argue that the cases involving discourse particles display a root/non-root asymmetry that we do not observe in the examples with genau (Sauerland \& Heck 2003). Accordingly, the question of why elements such as genau and discourse particles 
Given this evidence, and in accordance with the V2 constraint that holds in German, we thus claim that the $w h$-phrase and DiP must form a single constituent (contra Hinterhölzl \& Munaro this volume).

Meibauer (1994: 59) observes that, in all cases such as (8), the particle obeys a right adjacency constraint (i.e. [Prt+wh]-configurations are not attested). However, data such as (8') are not ungrammatical when the particle nur is interpreted as a conjunction-like element and not as a discourse particle, cf. the discussion revolving around focus particles (Büring \& Hartmann 2001).

(8') Nur wie habe ich den Schlüssel verlieren können?

In such examples, a clear prosodic break can be witnessed between nur and the rest of the clause, similar to English However, how could I have lost the key? Other discourse particles like schon (lit. 'already'), which lack the conjunction reading, are excluded from the position to the left of the wh-element (14c).

(14) a. Wie habe ich schon den Schlüssel verlieren können?

b. Wie schon habe ich den Schlüssel verlieren können?

'How could I lose the key? (Don't ask me! You already know it!)'

c. * Schon wie habe ich den Schlüssel verlieren können?

In section 3, we will come back to this issue of why the wh-element moves to the specifier of the particle phrase. After having showed that the co-occurrence of a wh-element and a discourse particle should be analyzed as one constituent, let us now turn to the issue of how this syntactic object is merged into the derivation.

\subsection{Left peripheral particles and generalized transformations}

In accordance with current minimalist approaches that assume interaction of subderivations (Gallego 2010; Stroik 2009; Trotzke \& Zwart 2014; Uriagereka 1999, 2011), essentially in the form of generalized transformations, we claim that there is no reason to believe that the cyclic organization of the grammar should stop at the arbitrary boundary of 'words'. In other words, " $[t]$ he process of insertion is [...] not sensitive to the nature of the representation it connects, nor to whether the host node is a terminal or not" (Ackema \& Neeleman 2004: 130). Crucially, in minimalism this cyclic organization of grammar follows automatically if we assume that "Merge always applies at the simplest possible form: at the root" (Chomsky 1995: 248). This constraint on structure building, the 'Extension Condition', determines that the derivation of complex sub-

appear in the left periphery has to be answered separately for both categories, with different answers forthcoming in each case. 
jects and adjuncts implies that the computational system has to deal with more than one root syntactic object at the same time (Hornstein \& Nunes 2014; Nunes 2012; Uriagereka 2011). Let us look at the following derivation of The man left (cf. Trotzke \& Zwart 2014: 144-146). As we can see in (15), the Extension Condition prevents a derivation where man in (15d) first merges with left because in this case the would have to be merged with man in a noncyclic manner. As a consequence, the computational system has to merge man with the in a separate derivation layer as seen in $(15 \mathrm{e}) .^{5}$

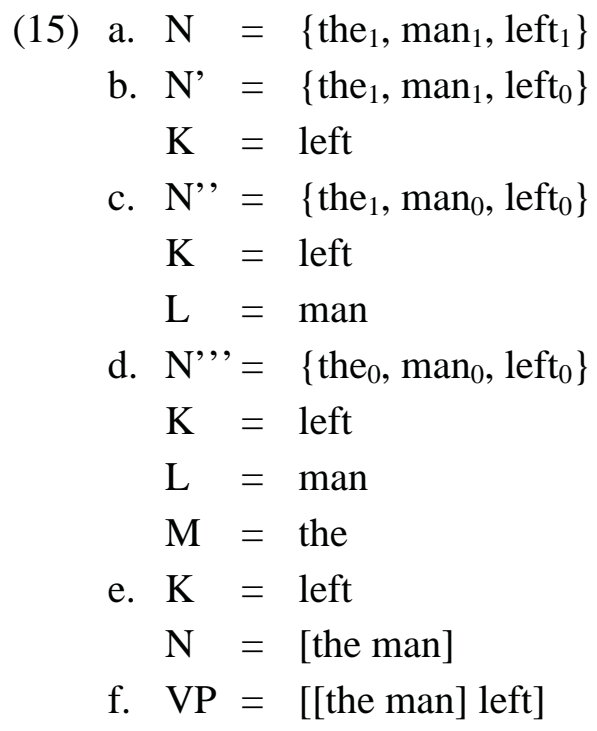

In contrast to the 'big' $\operatorname{PrtP}$ in $\left[\operatorname{PrtP} \operatorname{Prt}^{0}[\ldots[\mathrm{VP} / \mathrm{vP} \ldots]]\right]$ where $\operatorname{Prt}^{0}$ obviously appears in its scope position, we claim that the 'small' particle phrase (SPrtP) involving the wh-element is derived in a separate derivational process in which $\mathrm{Prt}^{0}$ is merged with the $w h$-element, and the $w h$-phrase is obligatory moved to the specifier of $\operatorname{Prt}^{0}$ (cf. section 2.1 above). SPrtP is then merged into the unfolding V-projection, the step after which successive-cyclic movement of SPrtP, analogous to $w h$-movement, may apply. Both the DiP and the $w h$-element are operators that must be licensed in a scope position. Accordingly, in addition to serving as an argument, SPrtP must raise to a position where the DiP can take scope. This is the derivational point at which DiP/Prt ${ }^{0}$ is deactivated and thus 'frozen in place'. The SPrtP as a whole cannot stop here, of course. The DiP is only one of the scope-taking operators involved. The other one is the wh-element. This has not been taken care of. Thus, as a final step, SPrtP must raise to a position where the wh-element can be licensed. This derivation sequence is summarized in (16).

$5 \mathrm{~N}$ is the 'numeration' with which a derivation starts. The index number says how often a lexical item (LI) occurs in the numeration; the number is zero once the LI has been merged in the derivation; for details, cf. Chomsky (1995). K, L, M refer to projected or unprojected LIs. 
Various reconstruction effects show that SPrtP must move through the VP/vP-related PrtP before it moves on to the checking destination of the wh-element. Crucially, DiPs have taken scope long before they make a physical appearance in SpecCP. The left edge of $\mathrm{VP} / v \mathrm{P}$, alias PrtP, is targeted in exactly the same way as the left edge of CP. In analogy with a silent C-head, the feature of a silent Prt-head is valued when SPrtP moves into its specifier. As (16) indicates, the lower copies of SPrtP are deleted in the phonological component. ${ }^{6}$ This analysis accounts for the irritating mobility of the DiP. It is easy to see now that the DiP has only been displaced for the reason of piedpiping. In the SPrtP, the DiP travels along with its $+w h$ co-constituent. In semantic terms, however, it is as immobile as the traditional descriptive accounts say. In sum, the DiP lacks any coregrammatical role in the CP's left periphery. Although we cannot offer a discussion of focus particles here, a proper account of focus particles in SpecCP as seen in (7) above is likely to rest on the same mechanism, namely that the focus particle has reached a scope position in the middlefield before it has been pied-piped together with its focus-associate to SpecCP. ${ }^{7}$

${ }^{6}$ Note that the pronunciation of multiple copies is not possible. A common restriction is that morphologically complex copies are less likely to be pronounced more than once (McDaniel 1986: 183; for discussion, cf. Nunes 2004).

(i) Wen glaubt Hans wen Jakob gesehen hat? whom thinks Hans whom Jakob seen has

'Who does Hans think Jakob saw?'

(ii) * Wessen Buch glaubst du wessen Buch Hans liest? whose book think you whose book Hans reads

'Whose book do you think Hans is reading?'

In section 3, however, we argue that SprtPs cannot appear in situ due to their interpretation in the semantic/pragmatic component.

7 If so, this could take care of the often-repeated argument that focus particles must take scope over CP because they take scope over QPs in CP. Consider the interpretation of (i).

(i) Nur Fleisch hat jeder gegessen

only meat has everybody eaten

a. For nothing but meat it is true that every person ate it.

b. For every person it is true that (s)he ate nothing but meat.

Reading $b$. is only possible under heavy stress of the universal quantifier. The dominant reading is a. But this cannot be an argument for nur taking wide scope because it occupies the highest position at PF. Under the assumption that the small particle phrase nur Fleisch moves through a pre- $v \mathrm{P}$ scope position, it attains scope over the $v$ P-internal QP at $\checkmark$.

(ii) [Nur Fleisch] hat ... [PrtP [nur Fleisch] $\operatorname{Prt}^{0} \checkmark$ [vP jeder [nur Fleisch] gegessen]] 


\subsection{Stacked left peripheral particles}

Through the work of Thurmair (1989) and Coniglio (2011) it is widely known that in German DiPs can co-occur in a simplex clause, and if they do, they tend to follow a strict hierarchy, much in analogy to the hierarchy of adverbs that Cinque (1999) has uncovered.
(17) a. Wo bist du denn bloß gewesen?
$($ denn $<$ blo $\beta)$
where are you PART PART been
'Where on earth have you been (I am wondering).'
b. * Wo bist du bloß denn gewesen?
c. Wo bist du denn gestern bloß gewesen?
$*($ blo $\beta<$ denn $)$
where are you PART yesterday PART been

Given the fact that they can be non-adjacent as in (17c), we can exclude the idea of a lexically reanalyzed 'super particle'. Each DiP seems to head its own phrase.

Notice now that DiPs can also be stacked in the SPrtP-construction as shown in (18), and if they are, they occur in the very same order as in the regular construction in which particles are merged with $\mathrm{VP} / v \mathrm{P}$ or its extensions.

(18) a. [Wie denn bloß] soll ich leben

$($ denn $<$ bloß $)$

how PART PART should I live

'How on earth should I live?'

b. * [Wie bloß denn] soll ich leben?

$*($ blo $\beta<$ denn $)$

At first sight, there seem to be counterexamples. Notice well-formed examples that seem to violate the ordering restriction. Consider (19), which appears to violate the order denn < blo 3 .

(19) [Wie bloß] soll ich denn leben?

$($ blo $\beta<$ denn $)$

However, one should not be deceived by linear order. Since in the present account linear order as such is irrelevant, (19) is no counterexample to the particle hierarchy we see in (17) and (18). The DiP bloß $3\left(\mathrm{Prt}_{2}\right)$ has taken scope in a Spec-Prt $2 \mathrm{P}$ position below $\operatorname{Prt}_{1} \mathrm{P}$ of which denn is the head. In fact, the well-formedness of examples such as (19) gives strong support to our account, according to which the DiP's occurrence in SpecCP is independent of its scopal property. 
(19') [[wie bloß] soll ich $: \begin{gathered}\text { denn-scope }\left(\operatorname{Prt}_{1}\right) \\ {[\operatorname{PrtP1} \text { denn }} \\ {[\text { [PrtP2 [wie bloß] [wie bloß] leben]]] }}\end{gathered}$

What matters for LF is the 'reconstructed' site in which the DiP has undergone scope freezing.

Notice now that our account in section 2.2 faces a serious problem when we want to account for constituents such as [wie denn bloß] in the left periphery of the clause. The problem with (18a) is that the order of the DiPs should actually be the reverse of what we see in the particle hierarchy in (18). As we saw in (19'), $\operatorname{Prt}_{2}($ blo $\beta)$ needs to acquire scope before $\operatorname{Prt}_{1}$ (denn). But in order to do so, $\mathrm{Prt}_{2}$ has to be the head of the phrase that is inserted in the developing Vprojection and not $\operatorname{Prt}_{1}$, as is the case in (20). ${ }^{8}$

\section{$\left[\operatorname{SPrtP1}\right.$ wh $\left[\operatorname{Prt} 1^{0}\left[\operatorname{SPrtP} 2 w h\left[\operatorname{Prt} 2^{0} w h\right]\right]\right]$}

In a minimalist system, however, we can solve this problem without any extra assumptions. In section 2.2, we already saw that the computational system has to operate with more than one root syntactic object at a time. If we understand movement as the interaction between the more basic operations Copy and Merge (Chomsky 1995), the operation of 'sideward movement' becomes a logical possibility within the computational system and its basic tools (cf. Bobaljik 1995; Nunes 1995; and Nunes 2012 for a recent overview). As (21) demonstrates, the stacked cases of left peripheral particles are empirical instantiations of sideward movement (we adopt the notational convention to annotate copies by superscripted indices).

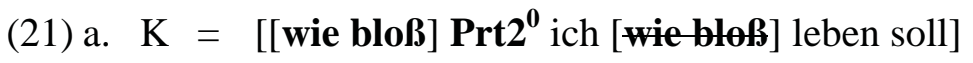

$\mathrm{L}=$ denn

b. $\mathrm{K}=\left[[\text { wie bloß }]^{\mathbf{i}} \operatorname{Prt}^{\mathbf{0}}\right.$ ich [wie bloß] leben soll $]$

$\mathrm{L}=$ denn

$\mathrm{M}=[\text { wie bloß }]^{\mathrm{i}}$

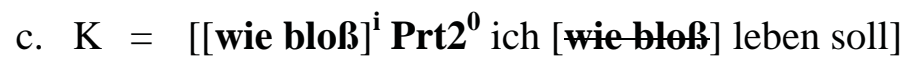

$\mathrm{P}=$ [wie denn [wie bloß] ${ }^{\mathrm{i}}$ ]

d. [[wie denn bloß] $\operatorname{Prt}^{0}{ }^{0}$ ich [wie bloß] leben soll]

e. $\left[\operatorname{Prt1}^{\mathbf{0}}\right.$ [wie denn bloß] $\operatorname{Prt2}^{\mathbf{0}}$ ich [wie bloß] leben soll]

f. [[wie denn bloß] $\operatorname{Prt1}^{0}$ [wie denn bloß] $\operatorname{Prt}^{\mathbf{0}}$ ich [wie bloß] leben soll]

In the derivation given in (21), $\operatorname{SPrtP}_{\mathrm{n}}$ is copied $(21 \mathrm{~b}, \mathrm{M})$ and merged not with the syntactic object containing the source of the copy, but with another root syntactic object $\left(\operatorname{Prt}_{n-1}\right)$ in a separate

8 Omitting some details, the derivation seen in (20) is what had been proposed in Bayer \& Obenauer (2011: §4). 
workspace $(21 \mathrm{c}, \mathrm{P})$. Since $\operatorname{Prt}_{\mathrm{n}-1}($ denn) needs a constituent it can take scope over, this copying operation complies with the general economy principle that every computational operation must be motivated as regards its interpretational result(s) at the interfaces ('Last Resort', cf. Chomsky 1995: 28). The output of merging $\operatorname{SPrtPn}\left(\right.$ wie bloß) with $\operatorname{Prt}_{\mathrm{n}-1}\left(\operatorname{SPrtP}_{\mathrm{n}-1}\right)$ is now inserted at the root of the syntactic derivation in (21d), in accordance with the Extension Condition and in contrast to non-cyclic operations as proposed by, e.g., Lebeaux (1991). Provided $P_{n-1} \neq \operatorname{Prt}_{n}, \operatorname{Prt}_{n-1}$ does not agree with the head of the PrtP whose specifier hosts $\operatorname{SPrtP}_{\mathrm{n}-1}$ at this stage. Accordingly, $\mathrm{SPrtP}_{\mathrm{n}-1}$ (wie denn blo $\beta$ ) contains an active operator feature. This feature will be deactivated upon merger of a new silent Prt-head $\left(\mathrm{Prt}^{0}{ }^{0}\right.$ ) with the (now) extended VP/vP-projection and raising $\mathrm{SPrtP}_{\mathrm{n}-1}$ to its specifier (21e-d). $\operatorname{Prt}_{\mathrm{n}-1}($ denn) undergoes scope freezing at this point and takes scope higher than $\operatorname{Prtn}(b l o \beta)$, as required by the attested hierarchy $($ denn $<$ blo $\beta)$. The process is summarized in Fig. 1.
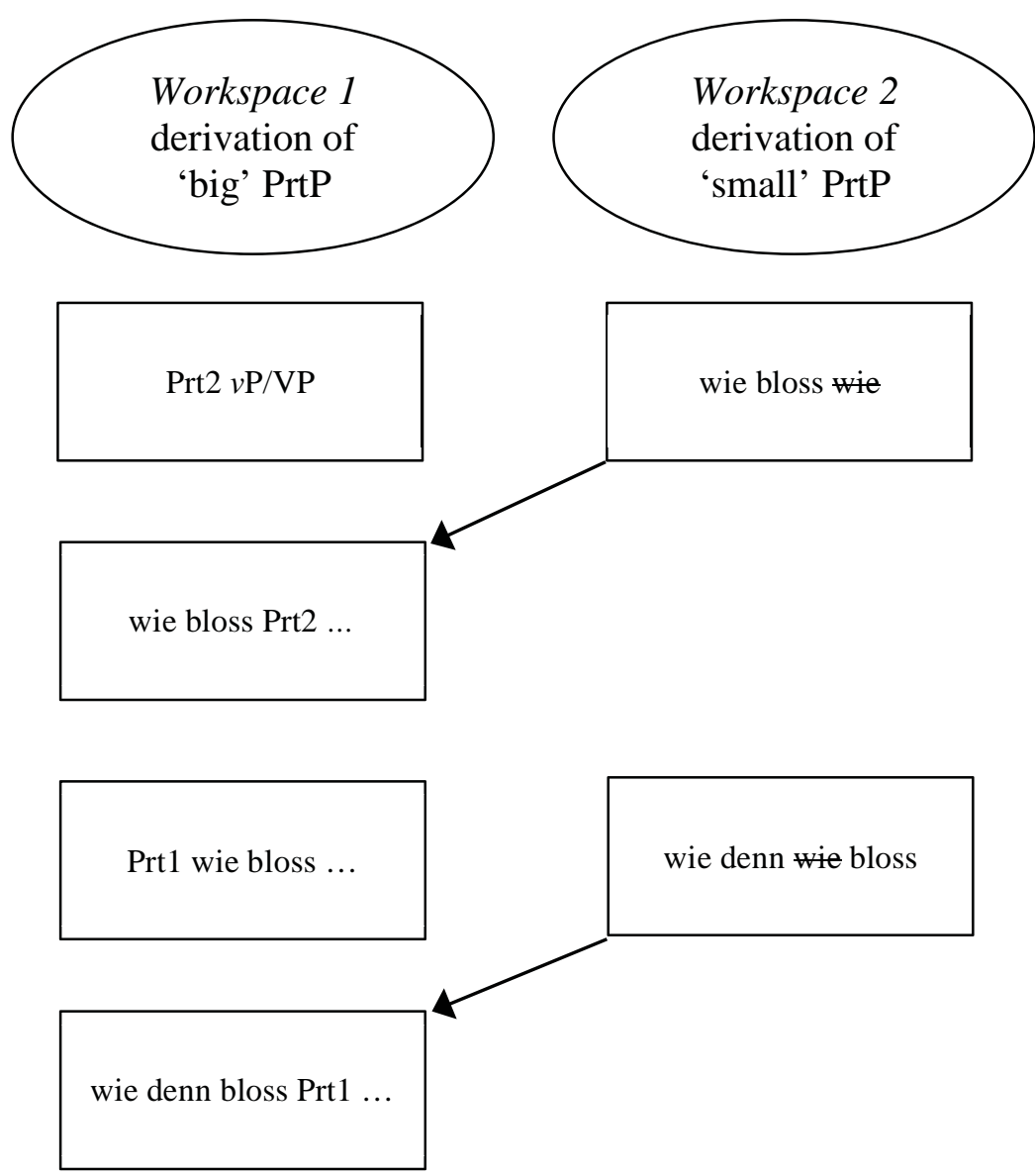

Fig. 1: Two derivation layers involved in the computation of stacked left peripheral particles.

In sum, by generalizing successive-cyclic wh-movement and by adopting the standard assumptions of generalized transformations (section 2.2) and sideward movement (this section), we can account for the syntactic distribution of DiPs in the left periphery of the clause. After having pro- 
vided the derivational details of configurations involving left peripheral particles, let us now turn to the interpretation we observe in the context of these constructions.

\section{Left peripheral particles and emphasis}

In this section, we address the interpretation of left peripheral occurrences of DiPs in German. In section 2.2, we showed that DiPs fulfill their discourse-semantic function already in the middle field of the clause by taking scope in a VP/vP-related position. Up to this point, it looks as if the formation of a SPrtP lacks semantic or pragmatic motivation and rather appears to be an optional quirk of the grammar of German. This is highly unlikely. But what is the function of the discourse particle in the left periphery then? In what follows, we claim that the left peripheral occurrence is associated with an extra touch of the speaker's emphasis, and we build on the notion of 'emphasis for intensity' as proposed by Trotzke \& Turco (submitted). In the literature, we sometimes find DiP-specific claims concerning this extra pragmatic effect. For instance, for the DiP nun (lit. 'now') in constructions such as Wann nun wird... ('When PRT will...'), Hinterhölzl \& Munaro (this volume) claim that the additional pragmatic effect can be characterized as the speaker's expression of a "strong exhortation to an immediate answer." This, however, is a DiPspecific interpretation and obviously does not hold for other cases, e.g. schon in [wh+schon]constructions, which yields a rhetorical question. Obviously, $[w h+\operatorname{Prt}]$ retains the semantic contribution that Prt makes to the illocutionary meaning in the 'big' PrtP but adds an extra pragmatic effect that is absent in the 'big' PrtP.

\subsection{The notion of emphasis for intensity}

Turning to the literature that discusses grammatical reflexes of emphasis, we find early proposals by Bierwisch (1966) and Kiefer (1967) that introduce the term 'emphasis' into research at the syntax-pragmatics interface. ${ }^{9}$ Kiefer (1967: 8) suggests to "conceive of emphasis as a device which consists of contrasting a particular constituent or constituents of the sentence with the corresponding constituents or constituents of another sentence." As should be clear from this definition, these proposals refer to word order options that are captured in terms of information structure in current research. A more useful notion of emphasis, for our purposes, is provided by the phonetic literature. There we find a clear-cut distinction between two types of emphasis: 'emphasis for contrast' and 'emphasis for intensity' (first mentioned by Coleman 1914). Emphasis for

9 Although the notion 'emphasis' was not used in his work, Otto Behaghel almost certainly identified it with the type of his Bedarfsstellungen ('positions on purpose') that serves to syntactically express the speaker's excitement (cf. Behaghel 1932: 8). 
contrast is typically associated to contrastive or corrective focus (cf. Umbach 2004). For instance, in the example John ate BANANA for breakfast (and not apples, pears, etc.), the contrasted element is singled out from a set of alternatives (Rooth 1992). Emphasis for intensity, on the other hand, has to do with expressive and attitudinal evaluation by amplifying the meaning of the emphasized constituent, as in There was an eNORmous queue waiting at the theatre (Niebuhr 2010). By highlighting the stressed syllable -NOR- of enormous, the speaker evokes a remarkability ranking, that is, an ordering of different crowd sizes, and, on this scale, he points to the upper portion of this scale, thereby expressing that the size of the queue was remarkable.

In the syntactic literature on left peripheral word order options in German, we find a similar notion of emphasis. Bayer $(1984,2001)$ shows that in Bavarian complement and also in certain adjunct $\mathrm{CPs}$ an XP can be fronted to SpecCP, and that this fronting endows the $\mathrm{CP}$ with an emphatic interpretation and forces it to undergo movement to the left periphery where it has access to the Force projection of the root clause. ${ }^{10}$ Frey (2010) discusses the observation that in German the question Wo ist Hans? ('Where is Hans?') can in principle be answered by (i) Er ist im KINO ('He is in the cinema') as well as by (ii) Im KINO ist er ('In the cinema is he'). He argues that choices such as (ii) yield a pragmatic effect that should not be analyzed in terms of information structure (i.e. in terms of emphasis for contrast). Rather, this effect goes beyond information structural interpretations by adding the evaluative dimension of speaker attitude to the meaning of an utterance (i.e. emphasis for intensity). Evaluating the fact that Hans is in the cinema as remarkable parallels the case involving the remarkable queue, where speakers express their subjective attitude, namely, according to Niebuhr (2010: 172), "either their admiration for the grandiose theatre performance or their irritation about the long waiting time."

However, many approaches, including Frey's (2010), analyze these speaker-related emphatic interpretations by a certain explication of the notion of contrast and thereby use the term 'emphasis' as an inclusive term encompassing different information structural interpretations (cf. also Hartmann 2008; Zimmermann 2008). They therefore readopt Kiefer's (1967) early proposal to use 'emphasis' as an umbrella term that includes all kinds of information structural meanings. In what follows, we will briefly illustrate that the notion of emphasis for intensity builds on information structure, but should not be identified with contrast. In this respect, we concur with recent work on Romance showing that evaluative meaning going beyond information structure in certain grammatical constructions can be analyzed as a focus-based implicature (Bianchi, Bocci \& Cruschina 2014).

\subsection{Emphasis for intensity in the left periphery}

In the context of the distinction between emphasis for contrast (information structural emphasis) and emphasis for intensity (expressing the speaker's emotional commitment), we observe an in-

\footnotetext{
${ }^{10}$ For an extension to the syntax of Bangla, cf. Bayer \& Dasgupta (in press).
} 
structive case involving particle elements in the left periphery when we turn to restrictions in topicalization patterns of particles in non-transparent particle-verb constructions. Given certain pragmatic conditions, verb particles can appear in the left periphery of the German clause. Müller (2002) and Zeller (2001) provide several examples, partly based on corpus evidence.

(22) (An derHaltestelle stiegen hübsche Frauen ein.)

(Zeller 2001: 89)

at the bus-stop climbed pretty women in.PART

AUS stiegen nur Männer.

out.PART climbed only men

'At the bus-stop, pretty women got in. Only men got off.'

Based on such examples, Zeller (2001: 93) concludes "that topicalization is restricted to phrases that are contrastively focused. This means that topicalization of a prepositional particle requires the existence of an alternative that this lexical element can be contrasted with" (in our case: einsteigen 'in-climb'). However, we observe several cases of topicalization where a verb-particle cannot be contrasted, such as (23a), backed up by corpus evidence and an acceptability study (Trotzke, Quaglia \& Wittenberg submitted). In (23), neither raus in rausfliegen (cf. *reinfliegen) nor in rausbringen (cf. * reinbringen) can be contrasted.

(23) a. (Stell Dir vor:) RAUS ist er gestern geflogen!

('Guess what!') out.PART is he yesterday flown

'He got kicked out yesterday.'

b. *(Stell Dir vor:) RAUS hat die Band ihr Album gebracht!

('Guess what!') out.PART has the band their album brought

'The band published their new album.'

A natural account in terms of information structure (emphasis for contrast) would be to analyze such configurations as 'pars-pro-toto-constructions' (Fanselow 2003). That is, elements that do not fulfill any discourse-semantic function in the left periphery alone can appear in the prefield 'pars-pro-toto', thereby highlighting the whole predicate. This is certainly the case in (23). However, this account cannot fully explain the difference we see in (23). Notice that while rausfliegen entails that someone has been dismissed in a harsh way, rausbringen does not refer to any such intensity scale that could serve as basis for expressing evaluation of the speaker: either the band published or did not publish. The option of topicalizing the particle in (23a) seems to depend on the lexical aspect of the verb and its aspectual composition with degrees (Caudal \& Nicolas 2005). This is also corroborated when we use a degree modifier such as regelrecht ('downright') in these constructions (for such diagnostics, cf. Kennedy \& McNally 2005), cf. Regelrecht raus ist (...) geflogen! vs. *Regelrecht raus hat (...) gebracht! In the context of these cases, we thus see that when a non-contrastable element occurs in the left periphery, the emphatic interpretation of the utterance rests on the lexical aspect of the verb, expressing a scale of intensity and, there- 
by, expressive content that can serve as a basis for the expression of the speaker's emphasis. Adopting a syntactic framework that attempts at encoding all semantic/pragmatic distinctions in the syntactic representation (Rizzi 2014), we could thus propose a Split-CP representation where the particle raus in the case of rausfliegen (23a) first moves to a Focus position 'pars pro toto' and then moves to an even higher projection that syntactically encodes the non-focal emphasis licensed by the expressive/evaluative predicate rausfliegen. ${ }^{11}$ This derivation is summarized in (24).

$$
\left[\mathrm{EmpP} \operatorname{raus}\left[\mathrm{Emp}^{0} \ldots\left[\mathrm{FocP} \text { raus }\left[\mathrm{Foc}^{0} \ldots[\mathrm{VP} / \mathrm{vP} \ldots \text { raus... }]\right]\right]\right]\right]
$$

After having illustrated the notion of emphasis for intensity in the context of particle-verb constructions, we now turn to the cases of left peripheral DiPs again.

\subsection{Emphasis for intensity and left peripheral particles}

In this section, we combine our remarks concerning emphasis for intensity with a reconsideration of configurations involving left peripheral DiPs. In this context, we already saw in section 2.1 that only DiPs can co-occur with the wh-element in the left periphery and not adverbs. An instructive case is the following ambiguity where we see that the adverbial reading is excluded as soon as schon appears as a co-constituent of a wh-element in the left periphery (Meibauer 1991: 227-228).

(25) a. Wer ist schon für die Wiedervereinigung? who is ADV/PART for the reunification ADV: 'Who already advocates the reunification?'

PART: 'Who on earth advocates the reunification? Nobody!'

b. Wer schon ist für die Wiedervereinigung? who PART is for the reunification 'Who on earth advocates the reunification? Nobody!'

This demonstrates that only DiPs can show up as a co-constituent of a wh-element in the left periphery and not adverbs. Crucially, adverbs, as semantically contentful elements expressing parts of the proposition, can occur in the left periphery alone, but DiPs never occur alone in the prefield (see section 2.1). But what is the function of the DiP in the left periphery?

${ }^{11}$ The licensing of exclamative utterances by evaluative modality is a well-known phenomenon in the literature, cf., e.g., Munaro \& Obenauer's (1999) discussion of 'surprise-disapproval questions' and the modal licensing of non-argumental was (lit. 'what') in this context. 
First, in contrast to higher adverbs, the DiP does not appear in the left periphery to fulfill the V2-requirement of German (for so-called 'formal movement', cf., e.g., Fanselow 2002). In this context, the $w h$-element suffices to yield a grammatical sentence. Accordingly, there must be a different reason why the DiP occurs in the left periphery. As is clear from our discussion in section 2.2 and 2.3, the DiP has no discourse-semantic function in the left periphery because it takes scope over the proposition in the middle field of the clause and, usually, stays in its base position where it takes scope. In fact, as we saw in section 2.3, [wh+Prt]-constructions involving stacked particles provide important evidence for the common assumption that the particle fulfills its discourse-semantic function in the middle field. Our account demonstrates that, as soon as we assume that particles are interpreted in a reconstruction position in the middle field, we correctly predict the grammatical orderings we saw in (19), repeated here for convenience as (26).

(26') [[wie bloß] soll ich $: \begin{gathered}\text { denn-scope }\left(\operatorname{Prt}_{1}\right) \\ {[\operatorname{PrtP1} \operatorname{denn}} \\ {\left[\operatorname{PrtP2} \text { [wie bloß } 3 \text {-scope }\left(\operatorname{Prt}_{2}\right)\right.}\end{gathered}$

Accordingly, blo $\beta$ in (26) does not fulfill any particle-specific semantic function in the left periphery. We hypothesize that these constructions show an emphatic effect, and that this effect can be accounted for in line with the patterns we saw in section 3.2. We thus claim that the derivation given in (16) must be extended by adding an extra step involving movement of the SPrtP to the specifier of EmpP. EmpP, as already suggested above, is located in the Force domain of the clause, but should not be identified with the function of clausal typing (cf. Abraham 2014; Haegeman 2014 for other Split-Force accounts that distinguish clausal typing from further illocutionary components).

\section{$\left[\operatorname{SprtP}\left[\operatorname{Emp}^{0}\left[\operatorname{SprtP}\left[\operatorname{Force}^{0} / \operatorname{Fin}^{0} \ldots\left[\operatorname{PrtP}_{\operatorname{SPrtP}}\left[\operatorname{Prt}^{0} \ldots[\mathrm{vP} / \mathrm{vP} \ldots \operatorname{SPrtP} \ldots]\right]\right]\right]\right]\right]\right.$}

If we analyze the $[w h+P r t]-c o n s t r u c t i o n$ as another instance of emphatic word order options involving the Force domain of the clause in the sense given in (27), then an important prediction is made: As in other cases of speaker-related syntactic configurations, we should observe a

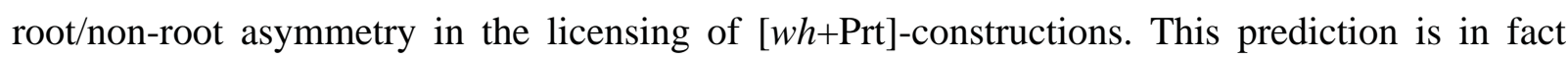

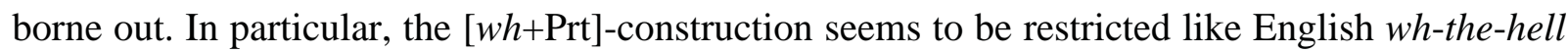
questions (Den Dikken \& Giannakidou 2002; Pesetsky 1987). That is, while a regular wh-phrase can stay in situ (cf. Wer kauft was? 'Who bought what?'), it is impossible that [wh+Prt] occurs in this position (cf. *Wer kauft was bloß?). In contrast to both the wh-element and the particle, the $[w h+\operatorname{Prt}]$-constituent must occur in the left periphery of the matrix clause. 
As for clausal complements, there is evidence that such complements can have all the signatures of speech acts as long as they are embedded under a matrix predicate that licenses reported speech. To see this, consider the following minimal pair from Bayer (2012: 15).

(28) a. Christine fragte, warum der Klaus denn so blass ist

Christine asked why the Klaus PART so pale is

b. * Christine weiß, warum der Klaus denn so blass ist

Christine knows why the Klaus PART so pale is

In (28a), the attitude of wondering/being concerned is ascribed to Christine and not to the speaker of the utterance because the verb fragen allows in its complement the report of a speech act. The epistemic verb wissen in (28b) does not license reported speech. Thus, the DiP denn cannot be linked to Christine's mental attitude. It cannot be linked to the actual speaker's attitude either because the speaker utters a declarative, a mood that is incompatible with this DiP. The same is true for emphatically marked $w h$-expressions of the type $[w h+P r t] .{ }^{12}$

(29) a. Die Skifahrer fragen sich, wo nur der Winter bleibt. the skiers ask themselves where PART the winter remains

'The skiers wonder where on earth winter has gone hiding.'

b. * Die Skifahrer wissen, wo nur der Winter bleibt.

Both the frustration impact of nur and the emphasis impact of the word order in wo nur must be ascribed to the attitude of the skiers, not to the attitude of the speaker who utters (29a). (29b) fails because the complement is not in the scope of a predicate that allows for a reported speech act. ${ }^{13}$

In sum, the $[w h+P r t]$-construction belongs to a class of constructions in which the speaker adds an extra touch of emphasis for intensity. Trotzke \& Turco (submitted) provide experimental phonetic evidence that substantiates this claim by demonstrating that the wh-element in the $[w h+\mathrm{Prt}]$-construction shows core distinct characteristics in comparison with a wh-element in clauses in which the DiP has remained in its lower base position. The phonetic side of $[w h+\mathrm{Prt}]$ is typical of emotive speech.

${ }^{12}$ Since many examples of this kind can be found in corpora, Thurmair's (1989: 26) conclusion that the $[w h+P r t]-c o n s t r u c t i o n$ cannot occur in indirect questions must be rejected.

${ }^{13}$ It is unclear so far why other examples of emphatic topicalization are less tolerant with respect to embedding. As Bayer $(1984,2001)$ has shown for the Bavarian dialect of German and Bayer \& Dasgupta (in press) have in addition shown for Bangla, there is emphatic topicalization to SpecCP in these languages which prevents the CP from remaining in its post-verbal position, irrespective of the selecting matrix predicate. In order to escape the problem, the emp-marked $\mathrm{CP}$ invariably undergoes movement to the matrix-clause and thus arguably enters the domain of the root's Force projection. 
So far it is unclear whether a grammatical notion of emphasis for intensity can be a common denominator of different examples including cases in which the wh-element is necessarily fronted and is necessarily unfocused as well. There is an interesting class of wh-questions in which the non-argumental wh-element was ('what') gains a why-like interpretation, whence the expression 'why-like what'. According to Munaro \& Obenauer (1999) and Obenauer (2004), these questions are notoriously associated with a critical attitude of the speaker ('surprisedisapproval questions'), and the speaker does not actually ask for information (although giving an answer in the sense of providing a reason would still be felicitous).

(30) a. Was stehst du hier herum?!

what stand you here around

'Why are you hanging around here?! (Get lost!)'

b. Was lachst du so blöd?!

what laugh you so stupidly

'Why are you laughing so stupidly?! (Stop it!)'

As we argued in section 3.2, the emphatic implicature builds on a set of alternatives by expressing an ordering of entities among the members of a set or a specific scale. That is also true for emphatic wh-questions; the emphatically marked wie in wie blo $\beta$ ('how only') from example (19) ranges over a set of manners (properties of events) whose identification is thought to be out of reach. When we turn to surprise-disapproval questions of the kind in (30), we see that the whelement obviously fails to range over a set of alternative values for reasons. Unlike the $w h$-item warum ('why'), why-like was cannot be focused and cannot occur in-situ in multiple questions.

(31) a. *WAS stehst du hier herum?! / *Wer steht hier WAS herum?!

b. WARUM stehst du hier herum?! / Wer steht hier WARUM herum?!

(32) a. * WAS lachst du so blöd?! / *Wer lacht WAS so blöd?!

b. WARUM lachst du so blöd?! / Wer lacht WARUM so blöd?!

As Bayer \& Obenauer (2011: 481-483) have shown, pseudo-questions of this kind are not only compatible with question-sensitive DiPs like denn but occasionally even require the DiP in order to derive the intended interpretation. ${ }^{14}$ The examples in (30) seem to even improve in idiomaticity when denn is added.

${ }^{14}$ This is the case in surprise-disapproval questions with wie as in

(i) Wie siehst DU denn aus?!

how look you PART out

'You look weird!'

Without denn, the utterance is likely to be interpreted as an information-seeking question. 
(33) a. Was stehst du denn hier herum?!

b. Was lachst du denn so blöd?!

This is in contrast with the sharp ungrammaticality of emphatic topicalization as in (34).

(34) a. * [Was denn] stehst du hier herum?!

b. * [Was denn] lachst du so blöd?!

The emphatic $w h$-construction shows that contrastability is a precondition for emphatic marking and emphatic topicalization. Although surprise-disapproval questions as in (30) and (33) are highly emotionally loaded and therefore surely emphatic in some sense, they are very different from those involving pied-piping of the DiP. ${ }^{15}$ We see that grammar encodes emphasis in a highly specialized form that can be associated but certainly not identified with a more general notion of emphasis that rests on a mix of phonetic intensity, voice quality, lexical choice, and other means.

\section{Conclusion}

In this chapter, we addressed the following two issues: (i) How can we derive the exceptional word order of constructions where DiPs show up in the left periphery? (ii) Do the different word orders of placing the particle in situ or in the left periphery correspond to different interpretations at the level of semantics/pragmatics? In order to address these questions, we based our analysis on the architectural properties of minimalist syntax. In particular, we assumed derivational cyclicity as constrained by the Extension Condition and by the copy theory of movement. In section 2, we provided a successive-cyclic movement derivation for the distribution of German DiPs in the left periphery, and we demonstrated that our approach accounts for the problematic cases of stacked particles appearing in the left periphery. In section 3, we turned to the internal order of the wh-element and the DiP in the small particle phrase (SPrtP) and proposed the notion of emphasis for intensity and emphatic topicalization to account for the interpretation of merging the SPrtP at the clausal level.

In our paper, we had to leave some issues open, both regarding the grammatical reflexes of emphasis in general and concerning the characteristics of the [wh+Prt]-constructions in particular. As for the grammatical reflexes of emphasis in general, it is an open issue how exactly our notion of emphasis for intensity connects to the more recent work on syntactic constructions expressing 'mirativity' (e.g. Cruschina 2011). This work also focuses on marked word orders that cannot (solely) be explained in terms of information structure. However, there are two reasons why we

${ }^{15}$ The same may be true for the cases of non-argumental (expletive) pronouns in European Portuguese which are in the service of emphatic marking according to Carrilho (2008). 
think that our notion of emphasis for intensity and emphatic topicalization is more appropriate to discuss the phenomena mentioned in our paper. As shown by Trotzke \& Turco (submitted), the pragmatic notion of mirativity, referring to unexpectedness/surprise of the speaker, may be too narrow to account for all cases that cannot be explained by referring to information structural categories. Second, and as a point concerning terminological choice, the term 'mirativity' stems form the typological literature investigating the mirative use of certain evidential markers. Crucially, as pointed out in this literature, "the mirative use doesn't participate in interrogative flip; in questions, the ME [= mirative evidential] cannot receive a mirative interpretation" (Rett \& Murray 2013: 461). Thus, the term 'mirativity' may be misleading when we want to account for the additional pragmatic effect observed also in the context of non-assertive speech acts such as wh-questions. A broader notion of speaker-related emphatic interpretations may be more appropriate to account for the variety of phenomena we observe cross-linguistically (Bayer \& Dasgupta in press; Kandybowicz 2013; Poletto \& Zanuttini 2013).

\section{References}

Abraham, Werner. 1991. Discourse particles in German: How does their illocutive force come about? In Discourse Particles: Descriptive and Theoretical Investigations on the Logical, Syntactic and Pragmatic Properties of Discourse Particles in German, Werner Abraham, 203-252. Amsterdam \& Philadelphia: Benjamins.

Abraham, Werner. 2014. Strong modality and truth disposability in syntactic subordination: What is the locus of the phase edge validating modal adverbials? Studia Linguistica To appear.

Ackema, Peter \& Ad Neeleman. 2004. Beyond Morphology: Interface Conditions on Word Formations. Oxford: Oxford University Press.

Bayer, Josef. 1984. Comp in Bavarian syntax. The Linguistic Review 3: 209-274.

Bayer, Josef. 1996. Directionality and Logical Form: On the Scope of Focusing Particles and Wh-in-situ. Dordrecht: Kluwer.

Bayer, Josef. 1999. Bound focus or how can association with focus be achieved without going semantically astray? In The Grammar of Focus, Georges Rebuschi \& Laurice Tuller, 5582. Amsterdam \& Philadelphia: Benjamins.

Bayer, Josef. 2001. Asymmetry in emphatic topicalization. In Audiatur Vox Sapientiae: A Festschrift for Arnim von Stechow, Caroline Féry \& Wolfgang Sternefeld, 15-47. Berlin: Akademie-Verlag.

Bayer, Josef. 2012. From modal particle to interrogative marker: A study of German denn. In Functional Heads, Laura Brugé, Anna Cardinaletti, Giuliana Giusti, Nicola Munaro \& Cecilia Poletto, 13-28. Oxford: Oxford University Press.

Bayer, Josef \& Probal Dasgupta. in press. Emphatic Topicalization and the structure of the left periphery: Evidence from German and Bangla. Syntax.

Bayer, Josef \& Hans-Georg Obenauer. 2011. Discourse particles, clause structure, and question types. The Linguistic Review 28: 449-491.

Behaghel, Otto. 1932. Deutsche Syntax: Eine geschichtliche Darstellung. Vol. IV. Heidelberg: Carl Winters Universitätsbuchhandlung. 
Bellert, Irena. 1977. On semantic and distributional properties of sentential adverbs. Linguistic Inquiry 8: 337-350.

Bianchi, Valentina, Giuliano Bocci \& Silvio Cruschina. 2014. Focus fronting, unexpectedness, and the evaluative dimension. http://ling.auf.net/lingbuzz/002166.

Bierwisch, Manfred. 1966. Regeln für die Intonation deutscher Sätze. Untersuchungen über Akzent und Intonation im Deutschen: Studia Grammatica 7: 99-199.

Bobaljik, Jonathan. 1995. Morphosyntax: The syntax of verbal inflection. Diss., MIT.

Büring, Daniel \& Katharina Hartmann. 2001. The syntax and semantics of focus-sensitive particles in German. Natural Language \& Linguistic Theory 19: 229-281.

Cardinaletti, Anna. 2011. German and Italian modal particles and clause structure. The Linguistic Review 28: 493-531.

Cardinaletti, Anna. this volume. Italian discourse particles in a comparative perspective.

Carrilho, Ernestina. 2008. Beyond subject doubling: expletive constructions in European Portuguese dialects. In Microvariation in Syntactic Doubling, Sjef Barbiers, Olaf Koeneman, Marika Lekakou \& Margreet van der Ham, 301-324. Bingley: Emerald.

Caudal, Patrick \& David Nicolas. 2005. Types of degress and types of event structures. In Event Arguments: Foundations and Applications, Claudia Maienborn \& Angelika Wöllstein, 277-300. Berlin \& New York: Mouton de Gruyter.

Chomsky, Noam. 1995. The Minimalist Program. Cambridge, MA: MIT Press.

Cinque, Guglielmo. 1999. Adverbs and Functional Heads: A Cross-Linguistic Perspective. Oxford: Oxford University Press.

Coleman, H.O. 1914. Intonation and emphasis. Miscellanea phonetica 1: 6-26.

Coniglio, Marco. 2011. Die Syntax der deutschen Modalpartikeln: Ihre Distribution und Lizensierung in Haupt- und Nebensätzen. Berlin: Akademie-Verlag.

Cruschina, Silvio. 2011. Discourse-related Features and Functional Projections. Oxford: Oxford University Press.

Den Dikken, Marcel \& Anastasia Giannakidou. 2002. From hell to polarity: 'Aggressively nonD-linked' wh-phrases as polarity items. Linguistic Inquiry 33: 31-61.

Ernst, Thomas. 2007. On the role of semantics in a theory of adverb syntax. Lingua 117: 10081033.

Fanselow, Gisbert. 2002. Quirky subjects and other specifiers. In More Than Words, Ingrid Kaufmann \& Barbara Stiebels, 227-250. Berlin: Akademie Verlag.

Fanselow, Gisbert. 2003. Surprising specifiers and cyclic spellout. Generative Linguistics in Poland 5: 29-46.

Frey, Werner. 2010. Ā-Movement and conventional implicatures: About the grammatical encoding of emphasis in German. Lingua 120: 1416-1435.

Gallego, Ángel J. 2010. Phase Theory. Amsterdam \& Philadelphia: Benjamins.

Haegeman, Liliane. 2014. West Flemish verb-based discourse markers and the articulation of the speech act layer. Studia Linguistica 68: 116-139.

Hartmann, Katharina. 2008. Focus and emphasis in tone and intonational languages. In The Discourse-Potential of Underspecified Structures, Anita Steube, 389-411. Berlin \& New York: Mouton de Gruyter.

Hinterhölzl, Roland \& Nicola Munaro. this volume. On the interpretation of modal particles in non-assertive speech acts in German and Bellunese.

Hornstein, Norbert \& Jairo Nunes. 2014. Minimalism and control. In The Routledge Handbook of Syntax, Andrew Carnie, Yosuke Sato \& Daniel Siddiqi, 239-263. London \& New York: Routledge. 
Jacobs, Joachim. 1983. Fokus und Skalen: Zur Syntax und Semantik der Gradpartikeln im Deutschen. Tübingen: Niemeyer.

Kandybowicz, Jason. 2013. Ways of emphatic scope-taking: From emphatic assertion in Nupe to the grammar of emphasis. Lingua 128: 51-71.

Kennedy, Christopher \& Louise McNally. 2005. Scale structure, degree modification, and the semantics of gradable predicates. Language 81: 345-381.

Kiefer, Ferenc. 1967. On Emphasis and Word Order in Hungarian. The Hague: Mouton.

Kleemann-Krämer, Anja. 2010. On apparent NP-internal focus particles in German. The Journal of Comparative Germanic Linguistics 13: 1-29.

Klein, Wolfgang \& Alexander Geyken. 2010. Das Digitale Wörterbuch der Deutschen Sprache (DWDS). Lexicographica: International Annual for Lexicography 26: 79-96.

Lebeaux, David. 1991. Relative clauses, licensing, and the nature of the derivation. In Perspectives on Phrase Structure: Heads and Licensing, Susan Rothstein, 209-239. San Diego: Academic Press.

Manzini, Rita M. this volume. Italian adverbs and discourse particles: Between recategorization and ambiguity.

McDaniel, Dana. 1986. Conditions on wh-chains. Diss., CUNY.

Meibauer, Jörg. 1991. Existenzimplikaturen bei rhetorischen W-Fragen. In Fragen und Fragesätze, Marga Reis \& Inger Rosengren, 223-242. Tübingen: Niemeyer.

Meibauer, Jörg. 1994. Modaler Kontrast und konzeptuelle Verschiebung: Studien zur Syntax und Semantik deutscher Modalpartikeln. Tübingen: Niemeyer.

Meyer, Marie-Christine \& Uli Sauerland. 2009. A pragmatic constraint on ambiguity detection. Natural Language \& Linguistic Theory 27: 139-150.

Müller, Stefan. 2002. Complex Predicates: Verbal Complexes, Resultative Constructions and Particle Verbs in German. Stanford: CSLI.

Müller, Stefan. 2003. Mehrfache Vorfeldbesetzung. Deutsche Sprache 31: 29-62.

Müller, Stefan. 2013. Datensammlung zur scheinbar mehrfachen Vorfeldbesetzung. Ms., FU Berlin, http://hpsg.fu-berlin.de/ stefan/PS/mehr-vf-daten.pdf.

Munaro, Nicola \& Hans-Georg Obenauer. 1999. On underspecified $w h$-elements in pseudointerrogatives. University of Venice Working Papers in Linguistics 9: 181-253.

Niebuhr, Oliver. 2010. On the phonetics of intensifying emphasis in German. Phonetica 67: 170198.

Nunes, Jairo. 1995. The copy theory of movement and linearization of chains in the minimalist program Diss., University of Maryland.

Nunes, Jairo. 2004. Linearization of Chains and Sideward Movement. Cambridge, MA: MIT Press.

Nunes, Jairo. 2012. Sideward movement: Triggers, timing, and outputs. In Ways of Structure Building, Myriam Uribe-Etxebarria \& Vidal Valmala, 114-142. Oxford: Oxford University Press.

Obenauer, Hans-Georg. 2004. Nonstandard wh-questions and alternative checkers in Pagotto. In The Syntax and Semantics of the Left Periphery, Horst Lohnstein \& Susanne Trissler, 343-383. Berlin \& New York: Mouton de Gruyter.

Pesetsky, David. 1987. Wh-in-situ: Movement and unselective binding. In The Representation of (In)Definiteness, Eric J. Reuland \& Alice G. Ter Meulen, 98-129. Cambridge, MA: MIT Press.

Poletto, Cecilia \& Raffaella Zanuttini. 2013. Emphasis as reduplication: Evidence from sì che/no che sentences. Lingua 128: 124-141. 
Reis, Marga. 2005. On the syntax of so-called focus particles in German: A reply to Büring and Hartmann 2001. Natural Language \& Linguistic Theory 23: 459-483.

Rett, Jessica \& Sarah E. Murray. 2013. A semantic account of mirative evidentials. Proceedings of SALT 23: 453-472.

Rizzi, Luigi. 2014. Syntactic cartography and the syntacticisation of scope-discourse semantics. In Mind, Values, and Metaphysics, Anne Reboul, 517-533. Dordrecht: Springer.

Rooth, Mats. 1992. A theory of focus interpretation. Natural Language Semantics 1: 75-116.

Sauerland, Uli \& Fabian Heck. 2003. LF-intervention effects in pied piping. In Proceedings of NELS 33, Makoto Kadowaki \& Shigeto Kawahara, 347-366. Amherst, MA: GLSA.

Sternefeld, Wolfgang. 2006. Syntax: Eine morphologisch motivierte generative Beschreibung des Deutschen. 2 Volumes. Tübingen: Stauffenburg.

Stroik, Thomas S. 2009. Locality in Minimalist Syntax. Cambridge, MA: MIT Press.

Thurmair, Maria. 1989. Modalpartikeln und ihre Kombinationen. Tübingen: Niemeyer.

Trotzke, Andreas, Stefano Quaglia \& Eva Wittenberg. submitted. Topicalization in German particle verbs: The role of semantic transparency. Submitted for publication.

Trotzke, Andreas \& Giuseppina Turco. submitted. The grammatical reflexes of emphasis: New evidence from German wh-questions. Submitted for publication.

Trotzke, Andreas \& Jan-Wouter Zwart. 2014. The complexity of narrow syntax: Minimalism, representational economy, and simplest Merge. In Measuring Grammatical Complexity, Frederick J. Newmeyer \& Laurel B. Preston, 128-147. Oxford: Oxford University Press.

Umbach, Carla. 2004. On the notion of contrast in information structure and discourse structure. Journal of Semantics 21: 1-21.

Uriagereka, Juan. 1999. Multiple spell-out. In Working Minimalism, Samuel D. Epstein \& Norbert Hornstein, 109-135. Cambridge, MA: MIT Press.

Uriagereka, Juan. 2011. Derivational cycles. In Oxford Handbook of Linguistic Minimalism, Cedric Boeckx, 239-259. Oxford: Oxford University Press.

Zeller, Jochen. 2001. Particle Verbs and Local Domains. Amsterdam \& Philadelphia: Benjamins.

Zimmermann, Malte. 2008. Contrastive focus and emphasis. Acta Linguistica Hungarica 55: 347-360. 